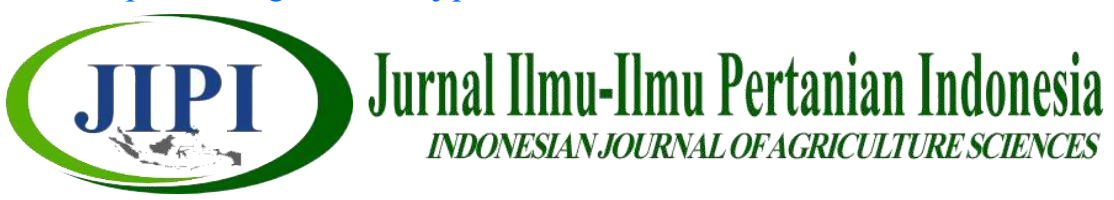

\title{
DAMPAK SISTEM OLAH TANAH DAN MULSA TANDAN KOSONG KELAPA SAWIT TERHADAP PERTUMBUHAN, HASIL JAGUNG MANIS (Zea mays saccharata) DAN TATA AIR TANAH
}

\author{
Andreas Junico Marulitua Situmorang ${ }^{1}$, Bandi Hermawan², \\ Hesti Pujiwati ${ }^{1}$ \\ ${ }^{1}$ Program Studi Agroekoteknologi, Fakultas Pertanian Universitas Bengkulu \\ ${ }^{2}$ Program Studi Ilmu Tanah, Fakultas Pertanian Universitas Bengkulu \\ * Corresponding Author : bhermawan@unib.ac.id
}

\begin{abstract}
[IMPACT OF THE TILLAGE SYSTEM AND OIL PALM EMPTY FRUIT BUNCH MULCH ON GROWTH, YIELD OF SWEET CORN (Zea mays saccharata) AND GROUNDWATER SYSTEM]. This study aims to determine the impact of land management and the use of oil palm empty fruit bunches (OPEFB) mulch. This research was conducted from August to October 2018, arranged in a split plot design with two factors. As a first factor, land management consists of unprocessed, plowed, and plowed and harrowed. The treatment of OPEFB mulch as the second factor consisted of no mulch, 9 tons/ha of mulch, 12 tons/ha of mulch, and 15 tons/ha of mulch. Plant variables observed consisted of plant height, stem diameter, number of leaves, fresh plant weight, plant dry, ear weight, ear length, ear diameter. Soil variables observed were the redistribution of groundwater and infiltration. The results showed no significant interaction between the tillage system and the application of OPEFB mulch on all observed variables. Treatment without tillage or mulch dose of 12 tons/ha can provide growth and yield of sweet corn plants better than other treatments. The highest water content and infiltration rate were obtained from the dosage of OPEFB mulch 15 tons/ha. Soil cultivation by plowing and harrowing produces the highest infiltration rate compared to lower tillage intensities. About $18 \%$ to $42 \%$ of the diversity of growth and yield of sweet corn plants have a significant relationship with the diversity of groundwater.
\end{abstract}

Keyword: groundwater, mulch, oil palm empty fruit bunch, sweet corn, tillage system

\begin{abstract}
ABSTRAK
Penelitian ini bertujuan untuk menentukan dampak dari pengolahan lahan dan penggunaan mulsa tandan kosong kelapa sawit (TKKS) terhadap pertumbuhan, hasil jagung manis dan tata air tanah. Penelitian ini dilakukan pada bulan Agustus hingga bulan Oktober 2018 disusun dalam Rancangan Petak Terbagi (Split plot) dengan dua faktor. Faktor pertama yaitu pengolahan tanah yang terdiri atas tanpa diolah, dibajak, serta dibajak dan digaru. Perlakuan mulsa tandan kosong kelapa sawit sebagai faktor kedua terdiri atas tanpa mulsa, mulsa 9 ton/ha, mulsa 12 ton/ha, dan mulsa 15 ton/ha. Variabel tanaman yang diamati terdiri atas tinggi tanaman, diameter batang, jumlah daun, bobot segar tanaman, bobot kering tanaman, bobot tongkol, panjang tongkol, diameter tongkol. Variabel tanah yang diamati yaitu redistribusi air tanah dan infiltrasi. Hasil penelitian menunjukkan tidak terdapat interaksi yang nyata antara sistem pengolahan tanah dan aplikasi mulsa TKKS pada seluruh variabel yang diamati. Perlakuan tanpa olah tanah atau dosis mulsa 12 ton/ha mampu memberi pertumbuhan dan hasil tanaman jagung manis yang lebih baik dibanding perlakuan lain. Kadar air dan laju infiltrasi tertinggi diperoleh dari dosis mulsa TKKS 15 ton/ha. Pengolahan tanah dengan cara dibajak dan digaru menghasilkan laju infiltrasi tertinggi dibandingkan intensitas pengolahan tanah yang lebih rendah. Sekitar 18\% sampai $42 \%$ keragaman pertumbuhan dan hasil tanaman jagung manis memiliki hubungan yang nyata dengan keragaman air tanah.
\end{abstract}

Kata kunci: air tanah, jagung manis, mulsa, sistem olah tanah 


\section{PENDAHULUAN}

Jagung manis atau yang dikenal dengan nama sweetcorn merupakan komoditas pertanian yang sangat digemari oleh masyarakat di Indonesia karena memiliki rasa yang manis dan banyak mengandung karbohidrat namun memiliki kadar lemak yang rendah. Budidaya jagung manis berpeluang memberi keuntungan yang relatif tinggi karena konsumsi jagung manis yang tinggi dan hampir semua bagian tanaman jagung manis memiliki nilai ekonomis, seperti batang dan daun sebagai pakan ternak, pupuk kompos dan pupuk hijau (Purwono \& Hartono, 2005). Nilai jualnya yang tinggi menyebabkan permintaan terhadap jagung manis semakin meningkat. Hal ini merupakan peluang usaha di pasar sehingga mendorong para petani untuk melakukan perbaikan terhadap sistem budidaya untuk meningkatkan produksi.

Salah satu usaha yang dapat dilakukan untuk meningkatkan produksi jagung adalah dengan perbaikan sifat fisik tanah melalui penerapan sistem olah tanah yang tepat. Olah tanah yang baik dan benar akan membuat struktur tanah menjadi remah, aerase tanah baik dan menghambat pertumbuhan tanaman penganggu (Akbar et al., 2012). Selain itu pengolahan tanah bertujuan memperbaiki kondisi tanah untuk penetrasi akar, infiltrasi air dan peredaran udara, menyiapkan tanah untuk irigasi permukaan dan pengendalian hama serta menghilangkan sisasisa tanaman pengganggu (Prasetyo et al., 2014). Pemberian mulsa dan pengolahan tanah secara nyata mempengaruhi sifat fisik tanah, pertumbuhan tanaman jagung dan meningkatkan kadar air tanah, bahan organik tanah, tinggi tanaman, hasil produksi dan penurunan kepadatan masal dan kekuatan tanah (Pervaiz et al., 2009).

Mulsa merupakan semua bahan yang digunakan pada permukaan tanah dan berfungsi untuk menghindari kehilangan air melalui penguapan dan menekan laju pertumbuhan gulma (Utama, 2013). Penggunaan mulsa organik merupakan pilihan alternatif yang tepat yang terdiri atas bahan organik sisa tanaman (seresah padi, serbuk gergaji, batang jagung, pangkasan dari tanaman pagar daun-daun dan ranting tanaman) yang dapat memperbaiki kesuburan, struktur tanah, dan secara tidak langsung akan memperbaiki struktur agregasi dan porositas tanah yang akan mempertahankan kapasitas tanah menahan air, setelah terdekomposisi (Hermawan, 2004).

Tandan kosong kelapa sawit (TKKS) merupakan limbah yang saat ini belum banyak dimanfaatkan. Tandan kosong biasanya hanya dijadikan mulsa pada lahan kritis atau dibakar dalam incinerator dan abunya dapat dimanfaatkan untuk membuat pupuk kalium, karena mengandung $30 \% \mathrm{~K}_{2} \mathrm{O}$. Selama dalam waktu yang relatif panjang limbah tersebut akan mendatangkan masalah, seperti terjadinya pencemaran. Upaya pemanfaatan limbah berupa TKKS tersebut diharapkan akan dapat mengurangi masalah pencemaran serta mendatangkan keuntungan dengan menjadi tingginya nilai limbah tersebut. Menurut Endriani (2010), bahan organik (bokashi tandan kosong kelapa sawit) mempunyai peranan yang sangat penting terutama pada perbaikan sifat fisik tanah yaitu meningkatkan kemampuan tanah menahan air, memperbaiki drainase dan tata udara tanah. Hasil penelitian Mercy (2009), menunjukkan bahwa pemberian mulsa cacahan TKKS dapat meningkatkan pertumbuhan tinggi tanaman dan diameter batang tanaman tomat. Produksi polong kacang tanah meningkat oleh perbaikan struktur tanah, penurunan nilai bobot isi, dan ketahanan penetrasi tanah akibat pemberian mulsa di permukaan tanah (Materechera, 2009). Selain memperbaiki sifat fisik tanah, mulsa juga dapat meningkatkan produksi tanaman pertanian.

Nilai jual tanaman jagung manis yang tinggi menyebabkan permintaan terhadap jagung manis semakin meningkat. Hal ini merupakan peluang usaha di pasar sehingga mendorong para petani untuk melakukan perbaikan terhadap sistem budidaya untuk meningkatkan produksi. Limbah TKKS jika tidak dimanfaatkan secara baik akan menimbulkan masalah pencemaran. Oleh karena itu pemanfaatan TKKS sebagai mulsa dapat mencegah terjadinya pencemaran serta meningkatkan pertumbuhan dan hasil tanaman jagung manis

Penelitian ini bertujuan untuk menjelaskan pengaruh interaksi sistem olah tanah dan dosis mulsa terhadap pertumbuhan dan hasil tanaman jagung manis dan tata air tanah, serta menentukan sistem olah tanah dan dosis mulsa paling efektif terhadap pertumbuhan dan hasil tanaman jagung serta tata air tanah.

\section{METODE PENELITIAN}

Penelitian ini dilaksanakan pada bulan Agustus Oktober 2018 di Kebun Percobaan Medan Baru dan di Laboratorium Ilmu Tanah Universitas Bengkulu. Jenis tanah lahan yang digunakan adalah jenis ultisol. Bahan yang digunakan dalam penelitian ini antara lain tanah, benih jagung varietas Bonanza, air, dan tandan kosong kelapa sawit. Alat yang digunakan dalam penelitian ini antara lain traktor, double ring infiltrometer, penggaris, ember, gayung, balok kayu, timbangan, ring sample, cangkul, sekop, stopwatch, cutter, tali rafia, kantong plastik, alat tulis dan peralatan laboratorium untuk menetapkan sifat-sifat fisik tanah. Percobaan disusun dalam rancangan petak terbagi yang terdiri dari 2 faktor yaitu faktor pengolahan tanah sebagai petak utama dan dosis mulsa sebagai anak petak. Faktor pengolahan tanah terdiri atas : Tanpa olah tanah, Tanah diolah menggunakan traktor (bajak), dan Tanah diolah menggunakan traktor (bajak + garu). Faktor dosis mulsa terdiri atas; tanpa mulsa, mulsa 9 ton/ha tandan kosong kelapa sawit $(6,048 \mathrm{~kg} /$ petak $)$, mulsa 12 ton/ha tandan kosong kelapa sawit $(8,064 \mathrm{~kg} /$ petak$)$, dan mulsa 15 ton/ha 
TKKS $(10,080 \mathrm{~kg} /$ petak $)$. Atas dasar kedua faktor tersebut diperoleh 12 kombinasi perlakuan yang masing-masing diulang sebanyak 3 kali. Data variabel tanaman yang dikumpulkan dianalisis secara statistik dengan Analisis Varian (ANAVA) dengan uji F pada taraf $5 \%$. Perbandingan rata-rata antar perlakuan dilakukan dengan Uji Beda Nyata Terkecil (BNT) pada taraf 5\% dan 1\%. Data variabel redistribusi air tanah dan infiltrasi air tanah dianalasis secara deskriptif.

\section{HASIL DAN PEMBAHASAN}

Lahan yang digunakan dalam penelitian memiliki permukaan datar dan seluruh permukaannya ditutupi rumput sebelum dilakukan tindakan pengolahan. Curah hujan pada saat penelitian relatif rendah ratarata $27,95 \mathrm{~mm}$ setiap bulannya, sementara curah hujan optimum untuk tanaman jagung manis adalah $300-600 \mathrm{~mm} / \mathrm{bulan}$. Oleh karena itu dilakukan penyiraman secara rutin untuk memenuhi kebutuhan air tanaman. Pada minggu kedua mulai tampak serangan hama dan penyakit tanaman, pada daun terlihat lubanglubang kecil akibat serangan belalang sehingga perlu dilakukan pengendalian. Pengendalian dilakukan dengan menggunakan insektisida berbahan aktif Deltametrin $25 \mathrm{~g} / \mathrm{L}$ dosis $4 \mathrm{ml} / \mathrm{L}$ air dan fungisida dengan bahan aktif Propinep 70\% dengan dosis 4g/L serta perekat berbahan aktif Alkilaril Polyoksietelien Glikol $440 \mathrm{~g} / \mathrm{L}$ dan Alkilaril Polyglicol $400 \mathrm{~g} / \mathrm{L}$. Pengendalian hama dan penyakit dilakukan secara rutin seminggu sekali dari munculnya serangan hingga seminggu sebelum panen. Pada umur 49 hari setelah tanam (hst) tanaman sudah mulai berbunga. Pemanenan dilaksanakan pada umur 75 hst.

Sistem olah tanah berpengaruh sangat nyata terhadap infiltrasi air tanah dan nyata pengaruhnya terhadap tinggi tanaman, diameter batang, bobot segar, dan bobot kering tanaman. Aplikasi mulsa berpengaruh sangat nyata $(P \leq 0,01)$ terhadap bobot segar, bobot kering tanaman dan kadar air tanah pada setiap kedalaman pengukuran serta berpengaruh nyata $(P \leq 0,05)$ terhadap tinggi tanaman, diameter batang, panjang tongkol tanpa kelobot, dan bobot tongkol tanpa kelobot. Interaksi antara kedua perlakuan berpengaruh tidak nyata $(P>0,05)$ terhadap setiap variabel pengamatan (Tabel 1).

Sistem olah tanah dengan cara dibajak cenderung menghasilkan pertumbuhan tanaman (tinggi tanaman, diameter batang, dan bobot kering tanaman) lebih baik dari tanpa olah tanah dan berbeda tidak nyata dari sistem olah tanah dibajak dan digaru (Tabel 2). Namun untuk mendapatkan bobot segar tinggi dibutuhkan pengolahan tanah dengan cara dibajak dan digaru. Pengolahan tanah dapat memperbaiki kelembaban tanah, daerah perakaran tanaman, aerasi tanah, mempercepat infiltrasi air tanah dan mengendalikan tumbuhan pengganggu (Suripin, 2004).
Tabel 1. Hasil analisis varians

\begin{tabular}{|l|c|c|c|}
\hline \multirow{2}{*}{ Variabel Pengamatan } & \multicolumn{3}{c}{ F-hitung } \\
\cline { 2 - 4 } & Sistem Olah Tanah & Mulsa & Interaksi \\
\hline Tinggi Tanaman & $25,79^{*}$ & $3,89^{*}$ & $0,61^{\mathrm{ns}}$ \\
\hline Diameter Batang & $32,93^{*}$ & $4,82^{*}$ & $049^{\mathrm{ns}}$ \\
\hline Jumlah Daun & $4,10^{\mathrm{ns}}$ & $0,36^{\mathrm{ns}}$ & $1,94^{\mathrm{ns}}$ \\
\hline Bobot Segar Tanaman & $98,57^{*}$ & $9,00^{* *}$ & $0,93^{\mathrm{ns}}$ \\
\hline Bobot Kering Tanaman & $29,77^{*}$ & $8,35^{* *}$ & $0,93^{\mathrm{ns}}$ \\
\hline Bobot Tongkol Tanpa Kelobot & $6.95^{\mathrm{ns}}$ & $4,66^{*}$ & $0,83^{\mathrm{ns}}$ \\
\hline Panjang Tongkol Tanpa Kelobot & $1.90^{\mathrm{ns}}$ & $4.31^{*}$ & $2,34^{\mathrm{ns}}$ \\
\hline Diameter Tongkol & $48,05^{\mathrm{ns}}$ & $2,44^{\mathrm{ns}}$ & $3,37^{\mathrm{ns}}$ \\
\hline Infiltrasi Air Tanah Lapangan & $48.45^{* *}$ & $3.21^{*}$ & $1.31^{\mathrm{ns}}$ \\
\hline Kadar Air Tanah 0-2,5 cm & $0.65^{\mathrm{ns}}$ & $37.43^{* *}$ & $0.71^{\mathrm{ns}}$ \\
\hline Kadar Air Tanah $2,5-5,0 \mathrm{~cm}$ & $1.69^{\mathrm{ns}}$ & $39.77^{* *}$ & $1.08^{\mathrm{ns}}$ \\
\hline Kadar Air Tanah $5,0-7,5 \mathrm{~cm}$ & $1.09^{\mathrm{ns}}$ & $16,66^{* *}$ & $0.76^{\mathrm{ns}}$ \\
\hline Kadar Air Tanah 7.5 $-1,0 \mathrm{~cm}$ & $1.43^{\mathrm{ns}}$ & $21.02^{* *}$ & $0.68^{\mathrm{ns}}$ \\
\hline
\end{tabular}

Keterangan : $\mathrm{ns}=$ berpengaruh tidak nyata $(\mathrm{P}>0,05)$

$*$ = berpengaruh nyata $(\mathrm{P} \leq 0,05)$

$* *$ = berpengaruh sangat nyata $(\mathrm{P} \leq 0,01)$

Daerah perakaran yang baik akan mempermudah tanaman dalam proses penyerapan unsur hara dan air dari dalam tanah. Pertumbuhan tanaman ditentukan oleh laju fotosintesis yang dikendalikan oleh ketersediaan unsur hara dan air. Semakin meningkat kecepatan infiltrasi tanah maka pergerakan air ke dalam tanah juga semakin tinggi sehingga mempermudah akar menyerap air untuk kebutuhan pertumbuhan tanaman (Hermawan et al., 2019).

Tabel 2. Rata-rata variabel pertumbuhan tanaman jagung manis pada sistem olah tanah

\begin{tabular}{cccc|c|c|}
\hline \multirow{2}{*}{ Sistem Olah Tanah } & \multicolumn{5}{c}{ Pertumbuhan Tanaman Jagung Manis } \\
\cline { 2 - 6 } & TT $(\mathrm{cm})$ & DB $(\mathrm{cm})$ & J (helai) & BST $(\mathrm{g})$ & BKT $(\mathrm{g})$ \\
\hline Tanpa Olah Tanah & $163,48 \mathrm{~b}$ & $1,72 \mathrm{~b}$ & 10,43 & $417,48 \mathrm{c}$ & $97,88 \mathrm{~b}$ \\
\hline Dibajak & $167,47 \mathrm{a}$ & $1.81 \mathrm{a}$ & 10,53 & $430,6 \mathrm{~b}$ & $100,36 \mathrm{a}$ \\
\hline Dibajak dan Digaru & $168,62 \mathrm{a}$ & $1,83 \mathrm{a}$ & 10,73 & $437,33 \mathrm{a}$ & $101,99 \mathrm{a}$ \\
\hline
\end{tabular}

Keterangan : Angka-angka yang diikuti oleh huruf yang sama pada kolom yang sama berbeda tidak nyata pada uji BNT 5\%. TT $(\mathrm{cm})=$ tinggi tanaman, DB $(\mathrm{cm})=$ diameter batang, JD (helai) = jumlah daun, BST $(\mathrm{g})=$ bobot segar tanaman, BKT (g) = bobot kering tanaman

Peningkatan tinggi tanaman dan diameter batang berpengaruh langsung terhadap bobot segar dan bobot kering tanaman. Hal ini juga diduga karena pengolahan tanah yang diterapkan dapat memperbaiki struktur tanah. Tanah dengan struktur baik akan mempunyai kondisi drainase dan aerasi yang baik pula untuk lebih memudahkan sistem perakaran tanaman dalam mengabsorpsi hara dan air, sehingga pertumbuhan dan produksi menjadi lebih baik (Sarief, 1980).

Perlakuan tanpa mulsa rata-rata menghasilkan pertumbuhan jagung manis yang terendah (Tabel 3). Pengaplikasian mulsa memberi pengaruh pada kondisi tanah yang berhubungan dengan ketersediaan bahan organik dan ketersediaan air. Aplikasi mulsa organik 
pada musim kemarau dapat meningkatkan kapasitas tukar kation tanah, kadar C organik, N, P, K, sehingga dapat meningkatkan hasil dan pertumbuhan tanaman cabai merah (Harsono, 2012).

Tabel 3. Rata - rata variabel pertumbuhan tanaman jagung manis pada beberapa dosis mulsa TKKS

\begin{tabular}{cccc|c|c|c}
\hline \multirow{2}{*}{ Mulsa } & \multicolumn{5}{c}{ Pertumbuhan Tanaman Jagung Manis } \\
\cline { 2 - 6 } & TT $(\mathrm{cm})$ & DB $(\mathrm{cm})$ & JD (helai) & BST $(\mathrm{g})$ & BKT $(\mathrm{g})$ \\
\hline Tanpa Mulsa & $159,98 \mathrm{~b}$ & $1,72 \mathrm{~b}$ & 10,5 & $409,96 \mathrm{c}$ & $95,77 \mathrm{c}$ \\
\hline 9 ton $/ \mathrm{ha}$ & $166,05 \mathrm{ab}$ & $1,79 \mathrm{ab}$ & 10,53 & $419,63 \mathrm{bc}$ & $98,35 \mathrm{bc}$ \\
\hline \multirow{2}{*}{12 ton/ha } & $168,72 \mathrm{a}$ & $1,80 \mathrm{a}$ & 10,63 & $430,90 \mathrm{~b}$ & $100,48 \mathrm{ab}$ \\
\hline 15 ton/ha & $171,33 \mathrm{a}$ & $1,83 \mathrm{a}$ & 10,57 & $453,36 \mathrm{a}$ & $105,70 \mathrm{a}$ \\
\hline
\end{tabular}

Keterangan : Angka-angka yang diikuti oleh huruf yang sama pada kolom yang sama berbeda tidak nyata pada BNT $5 \%$. TT $(\mathrm{cm})=$ tinggi tanaman, DB $(\mathrm{cm})=$ diameter batang, JD (helai) = jumlah daun, BST $(\mathrm{g})=$ bobot segar tanaman, BKT $(\mathrm{g})=$ bobot kering tanaman

Hasil penelitian Sunghening et al. (2013) menunjukkan bahwa mulsa dapat mempertahankan suhu dan kelembaban tanah, memperkecil penguapan air tanah sehingga tanaman dapat tumbuh dengan baik. Dengan demikian pemberian mulsa organik dapat menjaga ketersediaan air dalam tanah yang dibutuhkan oleh tanaman. Ketersediaan air dalam tanah sangat mempengaruhi pertumbuhan tanaman. Air yang digunakan oleh tanaman merupakan air tersedia yang terdapat di dalam pori-pori tanah pada lapisan perakaran tanaman (Wahyunie et al., 2012).

Mulsa tandan kosong kelapa sawit dapat menjaga kondisi tanah yang sesuai dan mendukung pertumbuhan tanaman. Aplikasi TKKS secara langsung sebagai mulsa di perkebunan kelapa sawit secara umum dapat meningkatkan kadar N, P, K, Ca, Mg, C-organik, dan KTK tanah (Darmosakoro \& Rahutomo, 2000). Bobot segar dan bobot kering tanaman ditentukan oleh akumulasi organ vegetatif tanaman oleh karena itu proses pertumbuhan yang baik akan sangat mempengaruhi bobot segar dan bobot kering tanaman. Pemulsaan mampu memperbaiki sifat fisik, kimia, dan biologi tanah sehingga mampu meningkatkan pertumbuhan tanaman (Murcitro et al., 2005). Mulsa dan pengolahan tanah dapat mempengaruhi sifat fisik tanah dan pertumbuhan tanaman jagung serta meningkatkan kadar air tanah, bahan organik tanah, tinggi tanaman dan hasil tanaman (Pervaiz et al., 2009).

Bobot tongkol tanpa kelobot terberat rata-rata 205,53 g dihasilkan oleh perlakuan olah tanah dengan cara dibajak. Untuk panjang tongkol tanpa kelobot terpanjang diperoleh pada perlakuan olah tanah dibajak dan digaru dengan panjang $17,84 \mathrm{~cm}$. Sedangkan pada diameter tongkol tanpa kelobot pengolahan tanah dengan cara dibajak menghasilkan rata-rata yang berbeda tidak nyata dengan dibajak dan digaru (Tabel 4).
Tabel 4. Rata-rata variabel hasil tanaman jagung manis pada sistem olah tanah

\begin{tabular}{|c|c|c|c|}
\hline \multirow{2}{*}{ Sistem Olah Tanah } & \multicolumn{3}{|c}{ Hasil Tanaman Jagung Manis } \\
\cline { 2 - 4 } & BTTK $(\mathrm{g})$ & PTTK $(\mathrm{cm})$ & DTTK $(\mathrm{cm})$ \\
\hline Tanpa Olah Tanah & 200,73 & 17,61 & $3.95 \mathrm{~b}$ \\
\hline Dibajak & 205,53 & 17,8 & $4.08 \mathrm{a}$ \\
\hline Dibajak dan Digaru & 205 & 17,84 & $4.11 \mathrm{a}$ \\
\hline
\end{tabular}

Keterangan : Angka-angka yang diikuti oleh huruf yang sama pada kolom yang sama berbeda tidak nyata pada BNT 5\%. BTTK $(\mathrm{g})=$ bobot tongkol tanpa kelobot, PTTK $(\mathrm{cm})=$ panjang tongkol tanpa kelobot, DTTK $(\mathrm{cm})=$ diameter tongkol tanpa kelobot

Pengolahan tanah dapat berpengaruh pada struktur, kemampuan menahan air, aerasi, infiltrasi, unsur hara, suhu dan evaporasi tanah (Andriani et al., 2013). Pengolahan tanah bertujuan untuk memperbaiki struktur tanah, memperbaiki daerah perakaran, memperbaiki aerasi dan kelembaban tanah, dan mempercepat infiltrasi. Olah tanah merupakan kegiatan memperbaiki kondisi tanah dengan proses pembalikan, penghancuran serta perataan tanah (Utomo, 2012).

Pengaplikasian mulsa TKKS dengan bobot 9 ton/ha dan 12 ton/ha sudah mampu memberikan hasil tanaman jagung manis yang berbeda tidak nyata seperti terlihat pada bobot tongkol tanpa kelobot, panjang tongkol tanpa kelobot dan diameter tongkol tanpa kelobot. Namun bobot tongkol tanpa kelobot terberat diperoleh pada pengaplikasian mulsa 15 ton/ha yaitu 210,30 g dengan produksi bobot tongkol tanpa kelobot rata-rata sebesar 7,5 ton/ha. Hasil ini masih di bawah deskripsi varietas dengan bobot tongkol tanpa kelobot diperkirakan 300 - $325 \mathrm{~g}$ dan produksi mencapai 10,71 - 11,60 ton/ha (Tabel 5).

Tandan kosong kelapa sawit sebagai mulsa organik dapat meningkatkan produksi tanaman dengan melepas unsur hara secara lambat ke tanah melalui mikroorganisme sehingga efektif dalam mendaur ulang unsur hara (Pratiwi, 2010). Peningkatan hasil ini juga diduga karena mulsa TKKS dapat memperbaiki sifat tanah. Perbaikan sifat tanah yang diperoleh dari aplikasi kompos TKKS secara umum berpengaruh terhadap peningkatan produksi tanaman (Amri et al., 2018 ; Simbolon et al., 2018). Aplikasi TKKS secara langsung sebagai mulsa di perkebunan kelapa sawit secara umum dapat meningkatkan kadar $\mathrm{N}, \mathrm{P}, \mathrm{K}, \mathrm{Ca}, \mathrm{Mg}, \mathrm{C}-$ organik, dan KTK tanah. Peningkatan hara tanah ini diharapkan dapat diikuti meningkatnya produksi tandan buah segar (TBS) (Darmosakoro \& Rahutomo, 2000). Hal ini didukung oleh Rismunandar (1992), bahwa cukupnya kebutuhan hara tanaman, maka pertumbuhan dan produktifitas tanaman akan berjalan efektif.

Pengaplikasian mulsa meningkatkan kelembaban tanah jika dibandingkan dengan tanpa mulsa, baik pada tanah diolah maupun tidak diolah. 
Efektvitas mulsa dalam menjaga kelembaban tanah di akhir musim tanam terlihat konsisten pada 4 lapisan perakaran ( $2,5 \mathrm{~cm} ; 5,0 \mathrm{~cm} ; 7,5 ; 10 \mathrm{~cm})$. Hubungan kelembaban dan bobot mulsa TKKS terlihat cenderung linear, dosis mulsa tertinggi menghasilkan kelembaban tertinggi.

Tabel 5. Rata - rata variabel hasil tanaman jagung manis pada beberapa dosis mulsa TKKS

\begin{tabular}{cc|ccc}
\hline \multirow{2}{*}{ Mulsa } & \multicolumn{4}{c}{ Hasil Tanaman Jagung Manis } \\
\cline { 2 - 5 } & BTTK $(\mathrm{g})$ & PTTK $(\mathrm{cm})$ & DTTK $(\mathrm{cm})$ & $\begin{array}{c}\text { BTTK } \\
\text { (ton/ha) }\end{array}$ \\
\hline Tanpa Mulsa & $196,80 \mathrm{~b}$ & $17,43 \mathrm{~b}$ & $4,00 \mathrm{~b}$ & $7,03 \mathrm{~b}$ \\
\hline 9 ton/ha & $202,80 \mathrm{ab}$ & $17,58 \mathrm{~b}$ & $4,02 \mathrm{ab}$ & $7,24 \mathrm{ab}$ \\
\hline 12 ton/ha & $205,10 \mathrm{a}$ & $17,85 \mathrm{ab}$ & $4,04 \mathrm{ab}$ & $7,33 \mathrm{a}$ \\
\hline 15 ton/ha & $210,30 \mathrm{a}$ & $18,13 \mathrm{a}$ & $4,13 \mathrm{a}$ & $7,50 \mathrm{a}$ \\
\hline
\end{tabular}

Keterangan : Angka-angka yang diikuti oleh huruf yang sama pada kolom yang sama berbeda tidak nyata pada BNT 5\%. BTTK $(\mathrm{g})=$ bobot tongkol tanpa kelobot, PTTK $(\mathrm{cm})=$ panjang tongkol tanpa kelobot, DTTK $(\mathrm{cm})=$ diameter tongkol tanpa kelobot

Mulsa TKKS dengan dosis 15 ton/ha memberikan nilai kadar air optimum pada setiap kedalaman perakaran serta sistem olah tanah (Tabel 6). Perlakuan mulsa. Hal ini disebabkan oleh pengaplikasian mulsa TKKS yang dapat menjaga kelembaban tanah serta mengurangi penguapan air dari dalam tanah. Penggunaan mulsa organik akan membantu mengurangi erosi, mempertahankan kelembaban tanah, memperbaiki drainase, mengurangi pemadatan tanah, meningkatkan kapasitas pertukaran ion, dan meningkatkan aktivitas biologi tanah (Antari et al., 2014).

Tabel 6. Rata-rata kadar air tanah lapangan terhadap pemberian mulsa TKKS

\begin{tabular}{|c|c|c|c|c|}
\hline \multirow{2}{*}{ Mulsa } & \multicolumn{4}{c}{ Tingkat kedalaman } \\
\cline { 2 - 5 } & $0-2,5 \mathrm{~cm}$ & $2,5-5,0 \mathrm{~cm}$ & $5,0-7,5 \mathrm{~cm}$ & $7,5-10 \mathrm{~cm}$ \\
\hline Tanpa Mulsa & $0,3874 \mathrm{~d}$ & $0,3897 \mathrm{c}$ & $0,3883 \mathrm{c}$ & $0,3875 \mathrm{~d}$ \\
\hline 9 ton/ha & $0,3941 \mathrm{c}$ & $0,3954 \mathrm{~b}$ & $0,3954 \mathrm{~b}$ & $0,3922 \mathrm{c}$ \\
\hline 12 ton/ha & $0,3971 \mathrm{~b}$ & $0,3992 \mathrm{a}$ & $0,3989 \mathrm{~b}$ & $0,3981 \mathrm{~b}$ \\
\hline 15 ton/ha & $0,4013 \mathrm{a}$ & $0,4015 \mathrm{a}$ & $0,4050 \mathrm{a}$ & $0,4038 \mathrm{a}$ \\
\hline
\end{tabular}

Keterangan : Angka-angka yang diikuti oleh huruf yang sama pada kolom yang sama berbeda tidak nyata pada BNT 5\%

Pemberian mulsa TKKS dapat mencegah terjadinya fluktuasi suhu tanah, sehingga kondisi suhu lingkungan rhyzosfer tetap terjaga dan mikroorganisme dapat berkembang dengan baik sehingga proses penguraian bahan organik tanah berlangsung dengan maksimal. Kondisi suhu tanah yang tetap terjaga maka air yang ada di dalam tanah akan tetap tersedia bagi tanaman. Meningkatnya kadar air di dalam tanah akan mengakibatkan proses absorbs dan transportasi unsur hara maupun air dalam tanah akan lebih baik sehingga pertumbuhan tanaman akan lebih bagi. Hasil penelitian Austin (2017) menunjukkan bahwa aplikasi TKKS sebagai mulsa berpengaruh sangat nyata terhadap kadar air tanah, suhu tanah siang (kedalaman 0-5 cm, $5-10 \mathrm{~cm}$, $10-15 \mathrm{~cm}$ ) dan suhu tanah sore kedalaman $0-5 \mathrm{~cm}$; serta berpengaruh nyata terhadap suhu tanah sore pada kedalaman $5-10 \mathrm{~cm}$.

Aplikasi mulsa TKKS pada permukaan tanah juga berdampak langsung terhadap evaporasi yang merupakan salah satu faktor yang mempengaruhi ketersediaan air didalam tanah. Penutupan tanah dengan mulsa dapat mempertahankan kelembaban tanah dari pengaruh langsung sinar matahari, sehingga kehilangan air tanah yang disebabkan oleh evaporasi menjadi berkurang (Aleksandro et al., 2016). Pemberian mulsa di atas permukaan tanah dapat menahan energi kinetis butiran air hujan sehingga agregat tanah tetap stabil.

Sistem pengolahan tanah dengan cara dibajak dan digaru dan pengaplikasian mulsa TKSS dengan bobot 9 ton/ha mampu menghasilkan nilai infiltrasi terbesar (Tabel 7). Kondisi tanah setelah mengalami pengolahan dengan cara dibajak dan digaru secara langsung mempengaruhi agregat tanah sehingga memungkinkan infiltrasi air tanah juga akan semakin cepat. Pengolahan tanah dapat berpengaruh pada struktur, kemampuan menahan air, aerasi, infiltrasi, unsur hara, suhu dan evaporasi tanah (Andriani et al., 2013).

Tabel 7. Infiltrasi Air Tanah Lapangan (cm/jam) terhadap sistem olah tanah dan beberapa dosis mulsa TKKS

\begin{tabular}{|c|c|}
\hline Sistem Olah Tanah & Infiltrasi Air Tanah Lapangan \\
\hline Tanpa Olah Tanah & $6,84 \mathrm{c}$ \\
\hline Dibajak & $9,36 \mathrm{~b}$ \\
\hline Dibajak dan Digaru & $10,44 \mathrm{a}$ \\
\hline & \\
\hline Mulsa & Infiltrasi Air Tanah Lapangan \\
\hline Tanpa Mulsa & $8,28 \mathrm{~b}$ \\
\hline 9 ton ha & $8,64 \mathrm{ab}$ \\
\hline 12 ton/ha & $9,00 \mathrm{ab}$ \\
\hline 15 ton/ha & $9,36 \mathrm{a}$ \\
\hline
\end{tabular}

Keterangan : Angka-angka yang diikuti oleh huruf yang sama pada kolom yang sama berbeda tidak nyata pada BNT 5\%

Refliaty et al. (2011) menyatakan bahwa pemberian bahan organik ke dalam tanah akan meningkatkan aktifitas mikroorganisme tanah sebagai pengurai bahan organik yang akan membentuk struktur yang remah dan membuat pori-pori di dalam tanah lebih banyak dan gembur sehingga bobot isi menjadi rendah. Semakin gembur 
dan semakin banyak pori dalam tanah akan mempercepat laju infiltrasi air di dalam tanah. Bahan organik dari aplikasi TKKS di atas permukaan tanah dapat meningkatkan populasi organisme dalam tanah, seperti cacing tanah (Khoiri et al., 2013). Pergerakan cacing di dalam tanah dapat membantu tebentuknya pori-pori di dalam tanah, sehingga total ruang pori meningkat.

Kadar air dan beberapa variabel pertumbuhan dan hasil tanaman jagung manis menunjukkan hubungan yang nyata (Tabel 8). Air merupakan komponen utama dalam suatu tanaman, bahkan hampir mencapai $90 \%$ sel-sel tanaman tersusun oleh air. Air yang diserap tanaman juga berfungsi sebagai media reaksi pada hampir seluruh proses metabolismenya. Evapotranspirasi merupakan salah satu proses metabolisme yang dialami oleh tanaman dimana air diuapkan melalui stomata (transpirasi) dan tanah (evaporasi) (Hanafiah, 2005). Air sangat berfungsi dalam pengangkutan atau transportasi unsur hara dari akar ke jaringan tanaman, sebagai pelarut garam-garaman, mineral serta sebagai penyusun jaringan tanaman (Jumin, 1992).

Tabel 8. Hubungan kadar air dengan pertumbuhan dan hasil tanaman jagung manis

\begin{tabular}{|c|c|c|c|c|}
\hline Variabel Pengamatan & a & b & $\mathrm{R}^{2}$ & Sig. \\
\hline Tinggi Tanaman & $-83,2359$ & 628,653 & 0,364 & 0,002 \\
\hline Diameter Batang & $-0,85505$ & 6,64459 & 0,31 & 0,005 \\
\hline Jumlah Daun & 10,63543 & $-0,1941$ & 0,00002 & 0,983 \\
\hline Bobot Segar & $-448,192$ & 2206,6 & 0,414 & 0,001 \\
\hline Bobot Kering & $-99,4651$ & 502,253 & 0,418 & 0,001 \\
\hline Bobot Tongkol Tanpa Kelobot & $-70,4135$ & 690,084 & 0,366 & 0,002 \\
\hline Panjang Tongkol Tanpa Kelobot & 5,306414 & 31,3243 & 0,179 & 0,039 \\
\hline Diameter Tongkol Tanpa Kelobot & 1,951589 & 5,27594 & 0,067 & 0,222 \\
\hline
\end{tabular}

Keterangan $: \mathrm{a}=$ konstanta, $\mathrm{b}=$ koefisien arah, $\mathrm{R}^{2}=$ koefisien determinasi

\section{KESIMPULAN}

Tidak terdapat interaksi yang nyata antara sistem pengolahan tanah dan pengaplikasian mulsa TKKS pada seluruh variabel yang diamati. Perlakuan tanpa olah tanah atau pengaplikasian mulsa 12 ton/ha mampu memberi pertumbuhan dan hasil tanaman jagung manis yang lebih baik dibanding perlakuan lain. Kadar air dan laju infiltrasi tertinggi diperoleh dengan pengaplikasian mulsa TKKS 15 ton/ha. Pengolahan tanah dengan cara dibajak dan digaru menghasilkan laju infiltrasi tertinggi dibandingkan intensitas pengolahan tanah yang lebih rendah. Sekitar 18\% sampai $42 \%$ keragaman pertumbuhan dan hasil tanaman jagung manis memiliki hubungan yang nyata dengan keragaman air tanah.

\section{DAFTAR PUSTAKA}

Akbar, A., Nugroho, A. \& Moenandir, J. (2012). Pengaruh Sistem Olah Tanah danWaktu Penyiangan pada pertumbuhan dan hasil Kedelai (Glycine $\max$ L.) Var. Grobogan. J. Budidaya Pertanian, 24
(1), 13-23.

Aleksandro, P., Wawan, Wardati. (2016) Sifat fisik tanah Dystrudepts di bawah tegakan kelapa sawit (Elais guineensis Jacq.) Fakultas Pertanian Universitas Riau yang diaplikasi mulsa organik Mucana bracteata. J. Online Mahasiswa, 3(1), $1-9$.

Amri, A.I., Armaini \& Purba, M.R.A. (2018). Aplikasi kompos tandan kosong kelapa sawit dan dolomit pada medium sub soil inceptisol terhadap bibit kelapa sawit (Elaeis guineensis Jacq.) di pembibitan utama. J. Agroekoteknologi, 8(2), 1-8. DOI: http:// dx.doi.org/10.24014/ja.v8i2.3349

Andriani, A., Suryanto, A. \& Sugito, Y. (2013). Uji metode pengolahan tanah terhadap hasil Wortel (Daucus carota L.) varietas Lokal Cisarua dan Takil Hibrida. Jurnal Produksi Tanaman, 1(5), 442-449. DOI : https://doi.org/10.21176/ protan.vli5.56.

Antari, R., Wawan \& Manurung, G.M.E. (2014). Pengaruh pemberian mulsa terhadap terhadap sifat fisik dan kimia tanah serta pertumbuhan akar kelapa sawit. J. Online Mahasiswa, 1(1), 1-13.

Austin, U. (2017). Dampak Lama Aplikasi Mulsa TKKS terhadap Sifat Tanah dan Perakaran Kelapa Sawit di Kebun Pt. Sari Aditya Loka 1, Kecamatan Air Hitam, Kabupaten Sarolangun. Skripsi. Fakultas Pertanian. Universitas Jambi, Pekanbaru.

Darmosakoro, W. \& Rahutomo, S. (2000). Tandan Kosong Kelapa Sawit sebagai Bahan Pembenah Tanah. In Prosiding : Lahan dan Pemupukan Kelapa Sawit. ed, Witjaksana, D., Edy. S. S. \& Winarna, Pusat Penelitian Kelapa Sawit, Medan, Desember 2003. pp 167-168.

Endriani. (2010). Sifat fisika dan kadar air tanah akibat penerapan olah tanah konservasi. Jurnal Hidrolitan, 1(1), 26-34.

Hanafiah, K.A. (2005). Dasar-Dasar Ilmu Tanah. Raja Grafindo Persada, Jakarta.

Harsono, P. (2012). Mulsa Organik : Pengaruhnya terhadap lingkungan mikro, sifat kimia tanah dan keragaman cabai merah di tanah Vertisol Sukoharjo pada musim kemarau. J. Hort Indonesia, 3(1), 35-41. DOI: https://doi.org/10.29244/ jhi.3.1.35-41.

Hermawan, B., Suhartoyo, H., Anandyawati, Murcitro, B.G., Agustian, I. (2019). Spatial variability in soil water under adjacent mature oil palm and rubber plantations: application of a new dielectric method in evaluating soil water. IJAT-AATSEA, 15(2), 261-271.

Hermawan, B. (2004). Penetapan air tanah melalui pengukuran sifat dielektrik pada berbagai tingkat kepadatan. Jurnal Ilmu-ilmu Pertanian Indonesia, 6(2), 66-74.

Jumin, H. B. (1992), Ekologi Tanaman suatu Pendekatan Fisiologi, Rajawi Press., Jakarta. 
Khoiri, A., Annom, A. \& Wawan. (2013). Perubahan Sifat Fisik Berbagai Jenis Tanah di Bawah Tegakan Kelapa Sawit (Elaeis guineensis Jacq.) yang Diaplikasi Tandan Kosong Kelapa Sawit (TKKS) di PT. Salim Ivomas Pratama. Skripsi. Fakultas Pertanian. Universitas Riau, Pekanbaru.

Materechera, S.A. (2009). Aggregation in a surface layer of a hardsetting and crusting soil as influenced by the application of amendments and grass mulch in a South African semi-arid environment. Soil \& Tillage Res., 105, 251-259. DOI : https:// doi.org/10.1016/j.still.2009.07.008.

Mercy, Y. B. (2009). Tingkat Kematangan Kompos Tandan Kosong Kelapa Sawit dan Penggunaan Berbagai Jenis Mulsa terhadap Pertumbuhan dan Produksi Tanaman Tomat (Lycopericon esculentum Miil.) dan Cabai (Capsicum anuum L.). Skripsi. Fakultas Pertanian, Institut Pertanian Bogor, Bogor.

Murcitro, B.G., Hermawan, B. \& Anggraeni, D. (2005). Pengaruh jenis tanaman penutup dan pengolahan tanah terhadap sifat fisika tanah pada lahan alang-alang. Jurnal Ilmu-ilmu Pertanian Indonesia, 7(1), 44-50.

Pervaiz, M.A., Iqbal, M., Shahzad, K. \& Hassan, A.U. (2009). Effect of mulch on soil physical properties and $\mathrm{N}, \mathrm{P}, \mathrm{K}$, concentration in maize (Zea mays) shoots under two tillage systems. Int. J. Agric. Biol, 11, 119-124.

Prasetyo, R.A., Nugroho, A. \& Moenandir, J. (2014). Pengaruh sistem olah tanah dan berbagai mulsa organik pada pertumbuhan dan hasil pertanaman kedelai (Glycine max (L.) Merr.) Var. Grobogan. J. Protan. 1(6), 486-495.

Pratiwi, P. (2010). Perubahan Beberapa Sifat Kimia Tanah dan Pertumbuhan Tanaman Jagung (Zea mays L.) Pada Ultisol Akibat Pemberian Limbah PKS dan Cacing Tanah. Skripsi. Fakultas Pertanian. Universitas Sumatera Utara, Medan.
Purwono \& Hartono, R. (2005). Bertanam Jagung Unggul.Penebar Swadaya, Jakarta.

Refliaty, Tampubolon, G., Hendriansyah. (2011). Pengaruh pemberian kompos sisa biogas kotoran sapi terhadap perbaikan beberapa sifat fisik ultisol dan hasil kedelai (Glycine max (L.) Merril). $J$. Hidrolitan, 2(3), 103-114.

Rismunandar. 1992. Tanah dan Seluk-beluknya Bagi Pertanian. Sinar Baru, Bandung.

Simbolon, J., Simanihuruk, B.W., Murcitro, B.G., Gusmara, H. \& Suprijono, E. (2018). Pengaruh substitusi pupuk N sintetik dengan limbah lumpur sawit terhadap pertumbuhan dan hasil jagung manis. Jurnal Ilmu-ilmu Pertanian Indonesia, 20 (2), 51-59. DOI: https://doi.org/10.31186/ jipi.20.2.51-59.

Sunghening, W., Tohari \& Shiddieq, D. (2013). Pengaruh mulsa organik terhadap pertummbuhan dan hasil tiga varietas kacang hijau (Vigna radiata $\mathrm{L}$. Wilczek) di lahan pasir Pantai Bugel, Kulon Progo. Vegetalika, 1(2), 1-13. DOI : https://doi.org/10.22146/veg.1519.

Suripin. (2004). Pelestarian Sumberdaya Tanah dan Air. Penerbit Andi, Yogyakarta.

Utama, H. U. (2013). Pengaruh lama penggunaan mulsa dan pupuk kandang pada pertumbuhan dan hasil tanaman jagung (Zea mays L.) varietas Potre Koneng. J. Produksi Tanaman. 1(4), 1-7.

Utomo, M. (2012). Tanpa Olah Tanah. Teknologi Pengelolaan Pertanian Lahan Kering. Lembaga Penelitian Universitas Lampung, Bandar Lampung.

Wahyunie, E.D., Baskoro, D.P.T. \& Sofyan, M. (2012). Kemampuan retensi air dan ketahanan penetrasi tanah pada sistem olah tanah intensif dan olah tanah konservasi. Jurnal Tanah Lingkungan, 14(2), 73-78. DOI: https://doi.org/10.29244/ jitl.14.2.73-78. 